\title{
Cmambu
}

\section{СТАНОВЛЕНИЕ ПАРАДИГМЫ ДЕЯТЕЛЬНОСТИ КАК ТЕОРЕТИКО-МЕТОДОЛОГИЧЕСКОЙ ДОМИНАНТЫ РАЗВИТИЯ РОССИЙСКОЙ ПСИХОЛОГИИ}

\author{
И.Н. СЕМЕНОВ
}

\begin{abstract}
Резюме
В статье на фоне краткого анализа истории российского человекознания XIX-XXI вв. охарактеризована системообразующая роль деятельностного подхода в качестве теоретикометодологической доминанты развития психологической науки. Впервые построена целостная периодизация этапов становления парадигмы деятельности и показано значение ее различных концепций для современной психологии. Их системодеятельностное взаимодействие позволило нам построить теоретическую модель, описывающую рефлексивно-личностную регуляцию мыслительной деятельности (при дискурсивном решении творческих задач) и рефлексивный механизм саморазвития личности в процессе продуктивной самодеятельности индивидуальности в сотворчестве с кооперантами. Онтологически деятельность есть преобразование объекта субъектом, опосредованное как орудийно-знаковыми средствами труда и общения (культурно-историческими по своему происхождению), так и субъектно-процессуальной динамикой рефлексивно-личностной регуляции этого преобразования. Ибо рефлексия обеспечивает значимое переосмысление и продуктивную перестройку содержания сознания субъекта для его адекватной ориентировки в биотической среде и социальном окружении как предпосылки адаптации поведения в них и конструктивного целеполагания и саморазвития индивидуальности во взаимодействии и взаимоотношении в процессе диалога с другими людьми - современниками, предшественниками и потомками, которые суть звенья эстафетной трансляции знаний и культур. Системообразующим фактором интеграции этих психических процессов, обеспечивающих в комплексе осуществление человеком социальной (по своей культурно-исторической природе) деятельности и индивидуально-диалогического поведения в коммуникациях, является рефлексия как переосмысление и перестройка субъектом жизнедеятельности переживаний души и содержания индивидуального сознания. В заключение показано перспективное значение для прогресса человекознания XXI в. парадигмы деятельности во взаимодействии с такими подходами психологии развития, как антропологический, метакогнитивный, психосемантический, рефлексивный, смысловой, персонологический, акмеологический, экзистенциальный, культуральный. Их экспериментальная верификация позволила разработать психотехнологии, эффективные для модернизации образования и управления в современную цифровую эпоху.
\end{abstract}

Ключевые слова: психология, человекознание, философия, методология, деятельностный подход, предметная деятельность, системодеятельность, действие, поведение, сознание, рефлексия, творчество. 


\section{Актуальность рефлексивно-науковедческого изучения развития деятельностного подхода}

Принцип предметной деятельности, единства сознания и деятельности является одним из базовых онтологических оснований российского человекознания, во многом определившим развитие в XX в. советской и в XXI в. постсоветской психологии (М.Я. Басов, С.Л. Рубинштейн, А.Н. Леонтьев, А.В. Петровский, К.А. Абульханова, А.В. Брушлинский, В.В. Давыдов) и системной методологии (Г.П. Щедровицкий, Н.Г. Алексеев, В.С. Швырев, Э.Г. Юдин). Актуальной исследовательской целью является изучение истории становления парадигмы деятельности как концептуально-методологической доминанты, системообразующего фактора российской психологии XX-XXI вв. До сих пор эта парадигма является точкой отсчета для оценки достижений психологии и теоретическим базисом для развития плюрализма ее современных направлений.

В связи с исследованиями определяющей роли деятельностного подхода в развитии российской психологии второй половины XX в. (А.Г. Асмолов, П.Я. Гальперин, В.П. Зинченко, А.А. Леонтьев, В.Д. Шадриков, М.Г. Ярошевский) историко-научный интерес представляет анализ недостаточно изученных социокультурных предпосылок зарождения и развития различных форм деятельностных представлений (Менчинская, Ферапонова, 1977) в истории российской психологии. Новизна такого рефлексивно-науковедческого изучения опирается на пропедевтику ее двухвековой хроники (Семенов, 2018б) и определяется единством социокультурного, науковедческого и персонологического аспектов анализа истории и логики развития дореволюционной (рубежа ХIX-XX вв.), советской (1918-1991) и постсоветской (1992-2020) психологии (Семенов, 2014a, 2019).

\section{Рефлексивно-науковедческий подход к изучению истории психологии}

В связи с разработкой рефлексивно-науковедческого подхода возникают важные методологические проблемы: 1) определения сущностной специфики советской психологии как оригинального направления мировой психологической науки XX в.; 2) характеристики значения деятельностных достижений российской психологии и изучения ее наследия в виде перспективных путей развития этой специфики в современной постсоветской психологии рубежа XX-XXІ вв.

Необходимо подчеркнуть, что в основательной ее историографии традиционно доминируют ядерные гносеологические аспекты психологического познания с весьма краткими сведениями о такой его периферии, как институционально-персонологическая субъектность, творчески порождающая знания (Семенов, 2013, 2014б, 2018a, 2019), и развивающие ее социокультурные условия (Семенов, 2018б). Интегрируя сведения из этих источников, получим емкую панораму истории российской психологии в виде фундаментальных трудов: М.В. Соколова (о психологических представлениях в средневековой 
Руси), Б.Г. Ананьева и Е.А. Будиловой (о психологии императорской России), А.В. Петровского, А.А. Смирнова, М.Г. Ярошевского, С.А. Богданчикова (о советской психологии), А.Н. Ждан, А.Л. Журавлева, Ю.П. Зинченко, В.А. Кольцовой, А.В. Юревича, Д.В. Ушакова (о постсоветской психологии), В.А. Петровского, И.Н. Семенова, Е.Б. Старовойтенко (о персонологии творчества в культуре).

Учет в единой онтологии указанных ядерных и периферийных аспектов истории человекознания позволяет с рефлексивно-науковедческих позиций (Семенов, 2014а) поставить проблему экспликации логики его развития в целях схематизации истории посредством построения сквозной, системной периодизации (Семенов, 2019), охватывающей психологию дореволюционную, советскую и постсоветскую в единой эволюции. Проблема ее периодизации методологически обсуждается (Е.А. Будилова, О.М. Тутунджян, Б.С. Братусь, В.А. Кольцова, С.А. Богданчиков, И.Н. Семенов) в различных аспектах: историко-хронологическом, социокультурном, предметно-познавательном, учебно-дидактическом и т.д. Наряду с этим при построении периодизации психологии необходим специальный анализ ее институционально-персонологического аспекта (Семенов, 2014a, 2014б, 2018a, 2018б). Он выражает субъектность научного творчества как познавательно-исследовательской деятельности (индивидуальной и коллективной), порождающей психологическое знание в конкретно-исторических условиях профессионального труда психологов и ученых смежных наук (историков, культурологов, философов, биологов, социологов, лингвистов, педагогов и т.д.) в определенных институциях.

Институционально-науковедческий анализ (Семенов, 2014a, 2018б, 2019) истории российской психологии позволяет выдвинуть гипотезу, что ее сущностной спецификой является деятельностный подход (Рубинштейн, 1922, 1945; Леонтьев А.Н., 1975) в различных его концептуальных вариантах, развитых на рубеже XX-XXI вв. Согласно следствиям из этой гипотезы зарождение идей о деятельности, а главное - становление теории и методологии их реализации - должны осуществляться в разной степени на всех этапах истории психологии, особенно советского времени (Семенов, 2018б).

Теоретическая разработка деятельностного подхода представлена в трудах С.Л. Рубинштейна $(1934,1945)$ и А.Н. Леонтьева $(1975,1986)$. Отмечается в его зарождении роль психологов (Басов, 1975, 2007a, 2007б, 2007в; Блонский, 1979; Выготский, 1930; Геллерштейн, 1933), философов (Богданов, 1990а, 1990б, 1990в; Гастев, 1924; Некрасов, 1902) и даже - педагогического психолога середины XIX в. К.Д. Ушинского (Днепров, 2007) и психофизиолога И.М. Сеченова (Рубинштейн, 1945; Ярошевский, 1984). Определенные С.Л. Рубинштейном и А.Н. Леонтьевым аспекты деятельности развили ведущие психологи середины ХХ в. (Гальперин, 1998; Мерлин, 1982; Смирнов, 1945; Теплов, 1944; Щедровицкий, 1995; Алексеев, 1962), а также ученые конца ХХ (Абульханова, 1980; Александров и др., 1999; Алексеев и др., 1991; Асмолов, 1985; Давыдов, Зинченко, 1998; Журавлев, 1992; Кан-Калик, 1977; Ломов, Сурков, 1980; Петровский А.В., 1982, 1987; Пономарев, 1981; Семенов, 1982; Тихомиров, 1969; Шадриков, 1982; Ярошевский, 1984) и начала XXI в. 
(Бодалев и др., 1996; Зинченко, 2011; Карпов, 2015; Калошина, 2013; Петровский В.А., 2011; Решетова, 2002; Сайко, 2008; Семенов, 2014а; Ушаков, 2003; Шадриков, 1996; Юревич, 2013; и др.).

Деятельностная парадигма достигла расцвета в школах ее основоположников: субъектно-процессуальной С.Л. Рубинштейна (К.А. Абульханова, Л.И. Анцыферова, В.Г. Асеев, А.В. Брушлинский, Е.А. Будилова) и мотивационнооперациональной А.Н. Леонтьева (А.В. Запорожец, Д.Б. Эльконин, А.А. Леонтьев, В.П. Зинченко, О.К. Тихомиров, А.Г. Асмолов, С.Д. Смирнов), а также их последователей в социально-психологической школе А.В. Петровского (М.Ю. Кондратьев, И.Б. Котова, В.А. Петровский, Л.Б. Шнейдер) и в психолого-педагогических школах П.Я. Гальперина (В.В. Давыдов, И.П. Калошина, 3.А. Решетова, Н.Ф. Талызина) и В.Д. Шадрикова (В.Н. Дружинин, А.В. Карпов, В.А. Мазилов, Г.А. Суворова). С учетом их достижений велось философское обобщение психолого-деятельностной проблематики в методологических школах Э.В. Ильенкова (В.В. Давыдов, В.В. Рубцов, В.И. Слободчиков), Г.П. Щедровицкого (Ю.В. Громыко, Н.И. Непомнящая, А.А. Пузырей, В.М. Розин) и Э.Г. Юдина (Н.Г. Алексеев, В.К. Зарецкий, В.М. Мунипов, И.Н. Семенов).

Эксплицируем логику развития российской психологии (дореволюционной/советской/постсоветской), выстроив периодизацию ее этапов в XIXXXI вв. с деятельностных позиций в контексте их реализации в ведущих институциях (лаборатории, кафедры, вузы), а также с учетом жизнетворчества персоналий их интеллектуальных и организационных лидеров. Жизнедеятельность ряда из них изучалась в специальных работах (Семенов, 1970a, 1970б, 1971, 2014б, 2018а, 2019), послуживших материалом для экспликации и рефлексии логики развития российской психологии (Семенов, 2014a, 2017, 2018б) наряду с науковедческим анализом массива историко-научных трудов о тех или иных этапах ее истории.

\section{Типология и периодизация развития деятельностных концепций в истории дореволюционной/советской/постсоветской психологии}

Обобщая пути и направления изучения проблематики деятельности, наметим следующую периодизацию ее становления с позиций институциональноперсонологического анализа истории психологии.

На первом - латентном - этапе во второй половине XIX в. параллельно с психологией души циркулировали (см.: Семенов, 1972а, 2018б) научные идеи о деятельности как о природе психики, изучаемой в контексте либо биологической эволюции ее физиологических механизмов (И.М. Сеченов, А.Н. Северцов, В.М. Бехтерев), либо о ее общественно-исторической обусловленности (А.А. Потебня, К.Д. Ушинский, Н.Я. Данилевский) в философско-антропологическом понимании человека (В.С. Соловьев, С.Л. Франк, Н.А. Бердяев, В.В. Зеньковский, Л.П. Карсавин) и деятельностного единства психической реальности в развитии взаимодействия ее природных и социальных начал (П.Ф. Каптерев, П.Ф. Лесгафт). Согласно психолого-педагогической антропологии 
К.Д. Ушинского, человек в идеале должен «подчинить стремление к бытию стремлению к жизни, а потому к деятельности сознательной и свободной, стремлению к свободному излюбленному труду» (цит. по: Днепров, 2007, с. 213).

На втором - интенииональном - этапе эти деятельностные ценности в начале XX в. повлияли на формирование идей в философии культуры личности и ее деятельности (Некрсов, 1902), а также в педагогике «свободного воспитания» К.Н. Вентцеля, «трудовой школы» П.П. Блонского и в «тектологии как всеобщей организационной науке» А.А. Богданова (см.: Семенов, 1970а, 1970б, 2013, 2014а). Таким образом, в эпоху Серебряного века (Семенов, 2018б) стала зарождаться собственно деятельностная логика развития российского человекознания, особенно в таких его сферах, как философия, психология, социология, педагогика. В эту эпоху в различных областях человекознания определяются интенции деятельностного подхода у философов (Богданов, 1990a, 1990б, 1990в; Некрасов, 1902), социологов (П.А. Сорокин, M.М. Ковалевский), психологов (Блонский, 1979; Рубинштейн, 1922), а также в исканиях педологов и педагогов, стремящихся воплотить эти интенции в жизнь в виде «трудовых установок» А.К. Гастева и «экспериментальной дидактики» А.П. Нечаева.

Предвестник системного подхода А.А. Богданов (на 20 лет опередивший Л. фон Берталанфи) разработал системно-методологическую концепцию «тектологии как всеобщей организационной науки» (от др.-греч. «строитель»). По А.А. Богданову (1990б), «научное познание представляет собой творчество норм целесообразности для практической деятельности». Законы природы он трактовал как «человеческие методы ориентировки в поле опыта, изменяющиеся сообразно с практическими потребностями», а организацию общества он представлял через организацию человеческого знания. Получив профессию врача в Харьковском университете, А.А. Богданов придавал большое значение системности естествознания, считая что «организующая деятельность всегда направлена к образованию каких-нибудь систем из элементов» (эти интенции через полвека реализовались в трудах другого врача-психолога из Харькова - П.Я. Гальперина). В психологии же начала XX в. элементы психики изучались в аспекте психофизиологии рефлексов и бихевиоризма поведения.

На третьем - поведенческом - этапе на рубеже 1910-1920-х гг. под влиянием ассимиляции бихевиоризма и физиологии рефлексов И.М. Сеченова И.П. Павлова происходит психофизиологическая редукция представлений о деятельности до ее рефлекторных механизмов и психофизиологических реакций индивида через их «поведенческое» гипостазирование. Это находит свое естественно-научное выражение в психоневрологии (затем «рефлексологии») В.М. Бехтерева, «поведенчестве» П.П. Блонского (см.: Семенов, 1970а, 1970б) и «реактологии» К.Н. Корнилова. В период послереволюционного зарождения в конце 1910-х гг. советской психологии эта «поведенческая психофизиология» рефлекторных реакций и действий декларативно служит механистической формой марксистского построения материалистической психологической науки, идеологически приемлемой для большевистских властей. 
На четвертом - педологическом - этапе в 1920-е гг. энтузиаст марксистской перестройки человекознания, философ-психолог П.П. Блонский выдвигает методологический план «реформы науки». Его ведущая теоретико-организационная роль в зарождении марксистской психологии недооенивается историками психологии, формально отдающими пальму первенства материалисту-реактологу К.Н. Корнилову (Богданчиков, 2015). Необходимо подчеркнуть, что в теоретическом плане П.П. Блонский придавал важное значение роли деятельности в развитии психики и в социальной жизни, поскольку: «человек есть homo technicus homo socialis... ключ к разгадке жизни человека... - техническая деятельность человеческого общества. Общественное производство является тем базисом, на котором основывается поведение человечества. Тем самым мы становимся на марксистскую точку зрения как на единственно научную» (Блонский, 1979, с. 184). Здесь проявляются социокультурные и психотехнические интенции будущей психологии деятельности. В методологическом плане П.П. Блонский считал, что «научная психология есть прежде всего генетическая психология» (Там же). В середине 1930-х гг. он исследует развитие памяти и мышления (образного и речевого, логического и рефлексивного), полемизируя с Л.С. Выготским (1930).

В 1920-е гг. П.П. Блонский реализует свой план «реформы науки» как теоретически (в ряде изданий «Очерков» научной психологии и учебников по педологии), так и практически - организуя с Н.К. Крупской (членом Коллегии Наркомпроса и при поддержке наркома А.В. Луначарского) вуз нового типа для обучения большевистских кадров - «Академию коммунистического воспитания» (АКВ). Здесь П.П. Блонский преподает и, разочаровавшись в конце 1920-х гг. в «поведенчестве» и педологии, ведет свои психологопедагогические исследования (в качестве председателя АКВ до 1931 г. и ее профессора до 1935 г.). При поддержке большевистских властей на рубеже $1910-1920$-х гг. именно руководимая им АКВ стала стартовой организационной институцией для зарождения с проектно-методологической интенцией (a не только с идеологической - как у К.Н. Корнилова и А.Б. Залкинда в ГНИИЭП) советской марксистской психологии. Другую существенную лепту в этот процесс внесла культурно-историческая школа, получившая пристанище в АКВ после ухода А.Н. Леонтьева и А.Р. Лурии из ГНИИЭП. Здесь при поддержке П.П. Блонского в 1927-1931 гг. А.Р. Лурия руководил психологической лабораторией (Е.Д. Божович, Л.С. Выготский, А.В. Запорожец, А.Н. Леонтьев и др.). Далее в 1930-е гг. ее участники переехали в Харьков, где в Психоневрологической академии УССР под руководством А.Н. Леонтьева (см.: Семенов, 2018а) вели эксперименты, ставшие заделом для построения им (с П.Я. Гальпериным, А.В. Запорожцем и др.) психологической теории деятельности.

Официозному становлению марксистской психологии способствовал Первый (после революции) психоневрологический съезд. Здесь в докладе «Психология и марксизм» ученик Г.И. Челпанова сотрудник ГНИИЭП К.Н. Корнилов предложил свою «реактологию» (наряду с «психоневрологией» В.М. Бехтерева) в качестве материалистической реализации марксизма в психологии. 
В соответствии с публикацией этого доклада в большевистской газете «Известия ВЦИК» (январь 1923 г.) официально датируется возникновение марксистской советской психологии. Однако К.Н. Корнилов лишь продолжил линию П.П. Блонского (по болезни не присутствовавшего на съезде), который предложил в 1919 и 1920 гг. план «реформы науки». Здесь он наметил один из путей его реализации посредством естественно-научного («поведенческого» и «рефлекторного») изучения материального субстрата психики. При этом другой - психолого-педологический - путь П.П. Блонский связывал с генетическим изучением развития психики в природной и социальной среде, акцентируя активность и орудийную деятельность человека. Позже на рубеже 1920-1930-х гг. это станет важным моментом в педологии М.Я. Басова (1975) и в генетической психологии П.П. Блонского (1979), а также в культурно-исторической теории Л.С. Выготского (1930) и А.Р. Лурии с ее имплицитно-деятельностными предпосылками (Давыдов, Зинченко, 1998; Wertsch, Vygotskii, 1981).

В конце 1923 г. Г.И. Челпанов был уволен из ГНИИЭП из-за «невнедрения» им в психологию марксизма, а ее большевистскую перестройку возглавил новый директор К.Н. Корнилов с позиций «реактологии». В связи с критикой (П.П. Блонским, Л.С. Выготским и др.) ее механицизма следующим директором ГНИИЭП стал в 1932 г. психолог-педолог А.Б. Залкинд. Он в начале 1920-х гг. также ратовал (с П.П. Блонским и К.Н. Корниловым) за создание советской психологии в качестве марксистской материалистической науки, а затем организовал в школах разветвленную педологическую службу и поддерживал психотехнику в прикладном изучении психологии труда и организации профессиональной деятельности педагогов как социально важный фон для педологии образования.

В конце 1920-х гг. заведующий кафедрой психологии ЛГПИ психолог-педолог М.Я. Басов считал: «Различного рода деятельность организма в окружающей среде, с помощью которой он устанавливает и выявляет свои взаимоотношения с нею, встает перед нами как предмет особого значения» (Басов, 1975, с. 236). Развивая учение А.Ф. Лазурского о «естественном эксперименте», М.Я. Басов разработал метод наблюдения, позволявший строить характеристику ребенка, основанную на материале, «охватывающем все формы активности ребенка во всех видах его деятельности, или, наоборот, относящемся к отдельным ее сторонам» (Там же, с. 163). По оценке М.Г. Ярошевского, именно М.Я. Басов являлся «пионером деятельностного подхода», хотя подчеркнем, что идея деятельности выдвигалась еще в дореволюционном человекознании (К.Д. Ушинский, И.М. Сеченов, П.А. Некрасов, А.А. Богданов), а после революции П.П. Блонским, А.К. Гастевым. Идея деятельности представлена в разделе «Развитие человека как активного деятеля в окружающей его среде. Психология развития» учебника «Общие основы педологии» (см.: Басов, 2007в). Отталкиваясь от организационной тектологии А.А. Богданова (см.: Семенов, 2013), М.Я. Басов приблизился к системному пониманию деятельности. Он разработал разноуровневую концепцию организации поведения и психологическую теорию развития субъекта в различных видах активной, 
творческой деятельности и общения (в таких их основных формах, как игра, учение, труд, наука и т.д.), а также метод наблюдения деятельности ребенка (Басов, 2007б) и изучения «волево-регуляции внешней деятельности» (Басов, 2007a). В развитие этого деятельностного подхода в качестве предмета психологического изучения социогенетическая реальность деятельности начала в 1930-е гг. разрабатываться в психолого-педологических трудах П.П. Блонского, Л.С. Выготского, А.Н. Леонтьева, С.Л. Рубинштейна.

При директоре А.Б. Залкинде в 1932-1934 гг. НИИП стал называться Государственным институтом психологии, педологии и психотехники с акцентированием соответствующей прикладной тематики. Это осложнило развитие культурно-исторической школы, участники которой (Л.И. Божович, Л.С. Выготский, А.В. Запорожец, А.Н. Леонтьев, А.Р. Лурия и др.) оставили ГНИИП, перейдя в АКВ - при поддержке ее председателя П.П. Блонского в психологическую лабораторию во главе с А.Р. Лурией. В начале 1930-х гг. А.Н. Леонтьев стал руководить в Харькове психолого-психотехническими экспериментами, которые привели к формированию его научной школы психологии деятельности (В.И. Аснин, Л.И. Божович, П.Я. Гальперин, А.В. Запорожец, П.И. Зинченко, Г.Д. Луков, Д.Б. Эльконин и др.).

На пятом - психотехническом - этапе в первой половине 1930-х гг. лидер психотехники И.Н. Шпильрейн был избран председателем ее международной ассоциации, 7-я конференция которой успешно прошла в 1931 г. в Москве. В связи с изданием новых русских переводов социоэкономических трудов К. Маркса и Ф. Энгельса в психологии стало актуальным изучение роли орудий труда в развитии психики и речи в организации деятельности человека (Выготский, 1930; Блонский, 1979; Басов, 1975). Возникли социокультурные предпосылки для психотехнического обращения к марксистской разработке психологических представлений о трудовой деятельности и ее определяющей роли в генезисе психики, речи, сознания и мышления (Геллерштейн, 1933; Рубинштейн, 1934; Леонтьев А.Н., 1975).

Однако в социокультурных условиях усиления в СССР сталинских репрессий произошел разгром педологии, психотехники, психоанализа, объявленный в 1936 г. в постановлении ЦК компартии «О педологических извращениях в системе Наркомпросов». Это существенно затормозило развитие психологии, в том числе из-за запрета трудов педологов (П.П. Блонский, Н.К. Вентцель, Л.С. Выготский, М.М. Рубинштейн), репрессий (М.Я. Басов, Н.Д. Левитов, А.П. Нечаев, Г.И. Челпанов, М.Г. Ярошевский) и расстрела психологов (Г.Г. Шпет, И.Н. Шпильрейн). Некоторые ученые были вынуждены издать статьи с самокритикой и осуждением педологии (С.Л. Рубинштейн, А.А. Смирнов и др.), а также приступили (Б.Г. Ананьев, Л.С. Выготский, А.Н. Леонтьев) к научной разработке применения позитивных марксистских идей для развития советской психологии (Геллерштейн, 1933; Рубинштейн, 1934).

На шестом - дидактическом (1935-1941) - этапе в предвоенное и «репрессивное» время присуждаются первые докторские степени (Б.Г. Ананьев, А.Р. Лурия, С.Л. Рубинштейн, Б.М. Теплов) в области педагогических наук с 
указанием «по психологии». При этом психологическая теория обобщается в основном в учебных пособиях: в 1938 г. издается базовый для педвузов учебник по психологии (под редакцией К.Н. Корнилова, А.А. Смирнова, Л.М. Шварца). В 1935 и 1940 гг. выходят монографические учебники по основам психологии и общей психологии С.Л. Рубинштейна. В них он систематизирует достижения мировой психологии первой трети ХХ в. и обосновывает принципы деятельностного подхода в психологическом познании. Эта «дидактическая» традиция развивалась далее в послевоенных учебниках Б.М. Теплова для средних школ и особенно для вузов (под редакцией А.А. Смирнова, А.Н. Леонтьева, С.Л. Рубинштейна, Б.М. Теплова), переизданных позднее в «оттепель», в 1956 и 1962 гг.

На седьмом - практическом (1941-1945) - этапе в военные годы Б.М. Теплов применял личностно-деятельностный подход в анализе актуальной для фронта проблематики «воли и ума полководца». В своем глубоком труде (вызвавшем интерес И.В. Сталина и маршалов) генерал в отставке профессор Б.М. Теплов (1990) вскрыл психологические механизмы практического мышления и воли личности гениальных военачальников (Александр Македонский, Ганнибал, Цезарь, Наполеон, Суворов, Кутузов и др.). Он охарактеризовал эффективную специфику их интуитивно-творческого интеллекта и принятия решений в индивидуальной полководческой деятельности (см.: Любимов, Семенов, 2015; Алексеев и др., 1991).

В целях экспериментально-практической верификации рефлекторного и деятельностного подходов были проведены также военно-психологические исследования в госпиталях под руководством П.Я. Гальперина, Ф.Д. Горбова, А.Р. Лурии, В.С. Мерлина, К.К. Платонова и др. В 1945 г. А.Н. Леонтьев и А.В.Запорожец издают книгу по восстановлению функций руки бойцов после ранений. С учетом этих и других практически значимых достижений военной и общей психологии директор ГНИИЭП в 1942-1945 гг. С.Л. Рубинштейн обобщил ее достижения с акцентом на анализе связи сознания и деятельности (Рубинштейн, 1945). В 1943 г. он был избран членом-корреспондентом АН СССР и за фундаментальный учебник по основам общей психологии удостоен Сталинской премии. Это ознаменовало официальное признание достижений советской психологии (в том числе ее развития с позиций деятельностного подхода), которые в 1946 г. были обобщены автором во втором дополненном издании данного учебника.

На восьмом - психофизиологическом (1945-1955) - этапе сразу после войны лидер советской психологии С.Л. Рубинштейн взял курс на анализ психологических аспектов классиков русской физиологии И.М. Сеченова и И.П. Павлова. Еще до печально знаменитой Павловской сессии двух академий 1950 г. С.Л. Рубинштейн стал анализировать рефлекторные механизмы психофизиологического функционирования процессов психической деятельности (восприятия, памяти, мышления) в созданном им в 1945 г. Секторе философских проблем психологии Института философии (ИФАН) АН СССР. Данная стратегия потом на полвека «запрограммировала» изыскания его научной школы (М.Г. Ярошевский, Е.А. Будилова, Л.И. Анцыферова, Е.В. Шорохова и 
др.). Эта материалистическая проблематика оказалась актуальной в связи с необходимостью реализации провозглашенного в 1950 г. на объединенной Павловской сессии двух академий (АН СССР и АМН СССР) К.М. Быковым и А.Г. Ивановым-Смоленским идеологического курса на «физиологизацию психологии» с целью замены ее учением И.П. Павлова о высшей нервной деятельности или, точнее, об условно-рефлекторной деятельности (как называл ее А.Г. Иванов-Смоленский). Важно подчеркнуть, что, отстаивая самостоятельность психологии, ряд ученых (Б.Г. Ананьев, П.К. Анохин, А.Р. Лурия, В.С. Мерлин, В.Н. Мясищев, Е.Н. Соколов, Б.М. Теплов и др.) конструктивно развернули исследования психофизиологическими и нейролингвистическими методами рефлекторных механизмов психической деятельности. В этом социокультурном контексте Б.М. Теплов (1985) создал крупнейшую в стране научную школу дифференциальной психофизиологии способностей и индивидуальных различий (см.: Абульханова и др., 2009; Любимов, Семенов, 2015; Семенов, 1972б, 2018б).

На девятом - общепсихологическом - этапе на рубеже 1950-1960-х гг. проблематика деятельности стала доминировать в теоретико-экспериментальных исследованиях, проводимых в школах С.Л. Рубинштейна и А.Н. Леонтьева. Каждая из школ имеет сложную, продуктивную и в целом известную историю (Абульханова, 1980; Леонтьев А.А., 2001; Леонтьев А.Н., 1975, 1986; Семенов, 2014a, 2018a, 2019; и др.). Отметим лишь, что после смерти И.В. Сталина, с середины 1950-х гг. в «оттепель» стали вновь издаваться оригинальные труды - по социокультурному развитию психики и мышления - предшественников идеи деятельности М.Я. Басова, П.П. Блонского, Л.С. Выготского и ее теоретиков С.Л. Рубинштейна и А.Н. Леонтьева.

С 1955 г. С.Л. Рубинштейн, восстановленный (после опалы 1948-1954 гг. из-за «космополитизма») в заведовании Сектором психологии ИФАН, публикует с позиций субъектно-деятельностной онтологии фундаментальные статьи и книги по проблемам бытия и сознания, мышления и речи, о принципах и путях развития психологической науки. Позднее ученики (К.А. Абульханова, А.В. Брушлинский и др.) издают его философско-психологические труды о человеке и мире, о гносеологии и методологии человекознания. Позднее это уже эпистемологически выходит за рамки деятельностной парадигмы, взаимодействуя на рубеже XX-XXI вв. с другими подходами: антропологическим, смысловым, рефлексивным, личностным, коммуникативным экзистенциальным (Абульханова, 1980; Абульханова и др., 2009; Асмолов; 1985; Журавлев, 1992; Зинченко, 2011; Леонтьев Д.А., 1998; Ломов, Сурков, 1980; Маланов, 2010; Петровский А.В., 1987; Семенов, 2017; Ушаков, 2003; и др.).

Автор другой - мотиващионно-операциональной - концепции деятельности А.Н. Леонтьев (1975), создав на организованном им в 1966 г. психологическом факультете МГУ крупнейшую в советской психологии школу (А.В. Запорожец, П.Я. Гальперин, Д.Б. Эльконин, Ю.Б. Гиппенрейтер, В.В. Давыдов, В.П. Зинченко, А.А. Леонтьев, О.К. Тихомиров, А.Г. Асмолов, Б.С. Братусь, И.Н. Семенов, С.Д. Смирнов и др.) экспериментальных исследований деятельности, также в своих поздних трудах онтологически пришел 
к метадеятельностному, рефлексивно-смысловому изучению связи предметной деятельности с сознанием личности, с образом ее мира и с творчеством в нем (Леонтьев А.Н., 1975). Естественно-научной базой для этого послужила его эволюционно-историческая концепция развития психики, за создание которой он был удостоен в 1963 г. Ленинской премии.

А.В. Петровский (см. о нем: Семенов, 2014б) с 1965 г. заведует кафедрой психологии в ведущем педагогическом вузе страны МГПИ и приступает к изучению творческой активности личности с позиций социально-психологического развития деятельностного подхода (Петровский А.В., 1982). В 1967 г. он издает первую в стране книгу по истории советской психологии. Здесь показана фундаментальная роль в ее развитии деятельностного подхода во взаимодействии с другими «недеятельностными» теориями: «комплексного человекознания» (Б.Г. Ананьев), «отношений» (В.Н. Мясищев), «активности» (Н.Ф. Добрынин), «установки» (Д.Н. Узнадзе), «интегральной индивидуальности» (В.С. Мерлин), «индивидуальных различий и способностей» (Б.М. Теплов) и т.д.

На десятом - психолого-педагогическом - этапе на рубеже 1960-1970-х гг. происходит операционализация деятельностного подхода, благодаря экспериментальным и прикладным исследованиям в школах последователей А.Н. Леонтьева. Так, его соратник П.Я. Гальперин в МГУ изучает ориентировочную деятельность, разрабатывая концепцию ориентировки как предмета психологии. По этой теории эффективность умственного действия зависит от типа организации его ориентировочной части, определяющей успешность исполнительной части действия, взаимодействующей с мотивационной и контрольной его частями. Исходя из этого, строились технологии обучения и учебники, чем обеспечивалась эффективность познавательной деятельности по основным учебным предметам. Соратники и последователи А.Н. Леонтьева (1975), П.Я. Гальперина (1998), Н.Ф. Талызиной, А.В. Запорожца, Д.Б. Эльконина, В.В. Давыдова, В.П. Зинченко, О.К. Тихомирова (1969) развивали деятельностную парадигму и реализующие ее психотехнологии в различных областях общей, возрастной, педагогической, компьютерной, инженерной психологии и эргономики. Эти технологии эффективно внедрялись в практику экспериментального обучения в ряде школ, вузов (Алексеев и др., 1991; Давыдов, Зинченко, 1998; Калошина, 2013; Кан-Калик, 1977; Решетова, 2002; Дюков и др., 2010; и др.), а также в профессиональном и военном образовании.

Параллельно этому А.В. Петровский разворачивает в ГНИИЭП изучение социально-психологической проблематики развития личности и групп (Петровский А.В., 1982) в контексте обеспечения образовательной практики с позиций модернизации парадигмы деятельности в виде теории деятельностного опосредствования (Петровский А.В., 1987; Петровский В.А., 2011). С учетом этого их соавтор (Петровский А.В. и др., 2001) по изучению теоретических основ психологии М.Г. Ярошевский организует изучение научной деятельности в созданном им в 1967 г. Секторе проблем научного творчества (Н.Г. Алексеев, Я.А. Пономарев, И.Н. Семенов, Б.А. Фролов и др.) Института 
истории естествознания и техники (ИИЕиТ) АН СССР. Позднее с учетом разработанных в школах А.Н. Леонтьева, С.Л. Рубинштейна, А.В. Петровского теории и методов социально-психологического изучения и развития личности в коллективах М.Г. Ярошевский создал в ИИЕиТ школу (А.Г. Аллахвердян, В.П. Карцев, М.И. Иванов и др.) социальной психологии науки и научной деятельности (см.: Юревич, 2013). Таким образом, деятельностный подход, реализуясь во взаимодействии психологии с философией, культурологией, социологией, науковедением, кибернетикой, эргономикой педагогикой, приобрел междисциплинарный характер. Для его обоснования потребовалось обращение к философии науки (Б.М. Кедров, В.А. Лекторский, В.С. Степин) и системнодеятельностной методологии (Г.П. Щедровицкий, Н.Г. Алексеев, В.А. Лефевр, В.Н. Садовский, В.С. Швырев, Э.Г. Юдин и др.) изучения мышления (Щедровицкий, 1995; Алексеев, 1962; Пономарев, 1981; Семенов, 1982, 2014а; и др.).

Начало развернувшегося в 1970-1980-е гг. одиннадцатого - системного этапа было инициировано созданием в конце 1971 г. Института психологии в системе АН СССР (ИПАН). В его состав вошли сформировавшиеся на основе разных предметных подходов лаборатории из ИФАН (заведующий Е.В. Шорохова), МГУ (О.К. Тихомиров), НИИОПП (В.Д. Небылицын) и специалисты по инженерной (Ю.М. Забродин, Д.Н. Завалишина, В.Ф. Рубахин) и социальной психологии (М.И. Бобнева, О.И. Зотова, К.К. Платонов и др.). Для их интеграции директору ИПАН Б.Ф. Ломову потребовался ряд подходов: когнитивный, коммуникативный, деятельностный и особенно системный. В 1970-е гг. системный подход был наиболее разработан в философии (В.П. Кузьмин, В.А. Лекторский, В.С. Швырев, Э.Г. Юдин), методологии (Г.П. Щедровицкий, В.Н. Садовский, Б.Г. Юдин), нейрофизиологии (П.К. Анохин, А.Р. Лурия, Е.Н. Соколов), инженерной психологии (Б.Г. Ананьев, А.А. Крылов, Б.Ф. Ломов, В.Н. Пушкин) и эргономике (Н.Г. Алексеев, В.П. Зинченко, В.М. Мунипов, И.Н. Семенов). Поскольку в ряде исследований был осуществлен конструктивный синтез концептуальных схем психологии деятельности (Алексеев и др., 1991) и методологических средств системного подхода (Щедровицкий, 1995; Юдин, 1978), то в советской психологии на рубеже 1970-1980-х гг. формируется системно-деятельностная парадигма (см.: Семенов, 2014a). Она оказалась конструктивной для развития общей психологии мышления и личности (Асмолов, 1985; Ломов, Сурков, 1980; Петровский А.В., 1987; Пономарев, 1981; Семенов, 1982; Шадриков, 1982; Ярошевский, 1984) и прикладной (В.А. Барабанщиков, Д.Н. Завалишина, В.П. Зинченко, А.А. Крылов, В.М. Мунипов, В.Ф. Рубахин и др.). На завершающем этапе советской психологии помощник президента СССР М.С. Горбачева крупный философ академик И.Т. Фролов создает при Президиуме АН СССР Центр изучения человека (директор-организатор В.П. Зинченко), а затем на его базе - Институт человека АН СССР (директор И.Т. Фролов, в 1990-е гг. - Б.Г. Юдин). Системно-деятельностный подход стал методологической основой для комплексного изучения человека в процессе организованного И.Т. Фроловым, Б.Ф. Ломовым, В.В. Давыдовым взаимодействия философов и 
психологов из различных институций (МГУ, ИПАН, ИФАН, НИИОПП, ВНИИТЭ, ЛГУ, ЯрГУ и др.), особенно в конце ХХ в. (Александров, и др. 1999, Алексеев и др., 1991; Бодалев и др., 1996; Давыдов, Зинченко, 1998; Журавлев, 1992; Шадриков, 1996).

На двенадцатом - плюралистическом - этапе (1992-2020) современной постсоветской психологии развиваются ее традиционные «советские» направления (в том числе возникшие на основе системно-деятельностной парадигмы) во взаимодействии с интенсивно ассимилируемыми зарубежными подходами (К.А. Абульханова, Д.Б. Богоявленская, В.Н. Дружинин, Д.А. Леонтьев, А.М. Матюшкин, В.А. Петровский, В.Ф. Петренко, Д.В. Ушаков, Т.Н. Ушакова и др.). В результате деятельностный подход обогащается новыми методами, творческое развитие которых российскими учеными ведет к ветвящемуся созданию таких его современных вариантов, как подходы культурно-деятельностный (А.Г. Асмолов, В.В. Давыдов, В.П. Зинченко, В.В. Рубцов, Б.Д. Эльконин), субъектно-деятельностный (К.А. Абульханова, A.В. Брушлинский, В.В. Знаков), профессионально-деятельностный (Л.Г. Дикая, Е.А. Климов, Ю.К. Стрелков, Г.В. Суходольский), креативно-деятельностный (Н.Г. Алексеев, Я.А. Пономарев, И.Н. Семенов), акмеолого-деятельностный (К.А. Абульханова, О.С. Анисимов, А.А. Бодалев, А.А. Деркач, В.Г. Зазыкин, И.Н. Семенов, Ю.В. Синягин, С.Ю. Степанов), деятельностноперсонологический (А.В. Петровский, В.А. Петровский, И.Н. Семенов, Е.Б. Старовойтенко), антрополого-деятельностный (В.П. Зинченко, М.К. Мамардашвили, В.И. Слободчиков, И.Т. Фролов), деятельностно-смысловой (А.А. Леонтьев, Д.А. Леонтьев, И.Н. Семенов, О.К. Тихомиров), рефлексивнодеятельностный (Н.Г. Алексеев, Г.И. Давыдова, В.М. Дюков, В.К. Зарецкий, И.Н. Семенов), деятельностно-семантический (А.А. Леонтьев, В.Ф. Петренко, А.Г. Шмелев), системодеятельностный (Г.П. Щедровицкий, Н.Г. Алексеев, И.Н. Семенов, Д.В. Ушаков), метасистемно-деятельностный (А.В. Карпов, В.Д. Шадриков) и т.д. Эти инновационные деятельностные подходы, взаимодействуя с недеятельностными концепциями (П.К. Анохин, Н.П. Бехтерева, А.А. Бодалев, Л.М. Веккер, В.С. Мерлин, Н.И. Чуприкова, В.Э. Чудновский и др.), образуют палитру современной психологии и способствуют теоретической интеграции (В.М. Аллахвердов, А.Г. Асмолов, А.Л. Журавлев, Ю.П. Зинченко, А.В. Карпов, Д.А. Леонтьев, В.А. Мазилов, В.А. Петровский, Э.В. Сайко, И.Н. Семенов, Д.В. Ушаков, В.Д. Шадриков, А.В. Юревич и др.) современного психологического знания.

Такая палитра в начале XXI в. представлена в 7-томном словаре «Психологический лексикон», изданном под редакцией первого президента PAО А.В. Петровского (Карпенко, Петровский, 2005-2007). Он спроектировал обобщение теоретических достижений мировой и российской психологической (в том числе советской и постсоветской) науки. Анализ этого энциклопедического труда и компендиума теоретической психологии (Петровский и др., 2001) показывает, что интегральный (деятельностный/системно-деятельностный/метасистемодеятельностный) подход является теоретико-методологической доминантой и системообразующим фактором становления в XX в. 
советской и развития в XXI в. постсоветской психологии, во многом определяя конструктивные перспективы ее развития во взаимодействии с другими концептуально-методологическими подходами.

\section{Заключение: значение изучения деятельности для классической и современной психологии}

В заключение подчеркнем онтологическую широту словоупотребления понятия «деятельность» в истории российского человекознания и психологии (Семенов, 2014a). В широком трансдисциплинарном смысле деятельность это психический процесс, задающий функциональную работу нервной системы, что закреплено в понятии «высшая нервная деятельность» в естественнонаучной рефлекторно-психофизиологической традиции (И.М. Сеченов, И.П. Павлов, В.М. Бехтерев). В социоэкономической традиции (К. Маркс, Ф. Энгельс, А.А. Богданов, П.А. Сорокин) деятельность - это орудийный труд, эксплуатация которого ведет к накоплению социального и человеческого капитала, обеспечивая прогресс цивилизации. Обобщение достижений российской психологии деятельности позволяет определить ее как психический процесс культурно мотивированного и социально нормированного преобразования субъектом объекта (на основе его предметного отражения) посредством формируемых в обучении умственных и исполнительных действий, констеллирующих закрепленный в знаковых системах знаний информационно-технологический опыт способов освоения природы и развития цивилизации (в том числе в орудийных, печатных, «интернетных», цифровых формах). В аксиологическом плане в российской психологии ХХ в. идея деятельности развивалась сначала прагматически как импульс организации (Богданов, 1990а) и ценность творчества (Рубинштейн, 1922), далее как психотехника труда (Геллерштейн, 1933), его марксистский идеал (Рубинштейн, 1945; Леонтьев А.Н., 1975), а затем параллельно с этой нормативной субстанциональностью (Щедровицкий, 1995; Гальперин, 1998) как творческая активность личности (Алексеев, 1962; Калошина, 2013; Кан-Калик, 1977; Петровский, А.В., 1982, 1987; Пономарев, 1981) в социокультурном бытии человека, рефлексивно осмысляющего (Леонтьев Д.А., 1998; Семенов, 2017) и самореализующего себя в мире посредством деятельности (Абульханова и др., 2009; Петровский В.А., 2011; Семенов, 2014; Шадриков, 1996). Эти системнопознавательные достижения (Карпенко, Петровский, 2005-2007) культурнодеятельностного подхода получили признание в зарубежной психологии (Matthaus, 1988; Semionov, 1978; Wertsch, Vygotskii, 1981).

Важно подчеркнуть, что в истории советской психологии принцип деятельности был: 1) не только прагматически и идеологически удобен (ибо в государстве трудящихся деятельность аксиологически тождественна труду), но и 2) онтологически адекватен (ибо деятельность знаменовала собой активность членов общества, устремленную на целесообразные для его прогресса деяния, в особенности обеспечивающие строительство социализма); 3) политически конкурентоспособен (как марксистская альтернатива буржуазной 
психологии в виде бихевиоризма и фрейдизма); 4) гносеологически применим для психологии (как новый предмет в отличие от традиционно изучаемых компонентов души (Семенов, 1972а): чувств и сознания, воли и поведения); 5) праксиологически полезен (ибо оптимизация организации способов деятельности повышает ее эффективность и служит средством обеспечения роста производительности труда и развития человеческого капитала с персонологически-креативным использованием рефлексивно-смысловых ресурсов деятельности).

На современном же этапе российской психологии выяснилось (Семенов, 2014a, 2018б), что позитивные достижения марксистски ориентированного изучения деятельности должны быть конструктивно использованы в контексте ее гуманизации «с человеческим лицом» (Леонтьев Д.А., 1998). При дальнейшей ассимиляции согласно принципу дополнительности - других подходов (от системного, цифрового через рефлексивный, экзистенциальный до культурологического и гуманистического) деятельностная парадигма в метасистемной трансформации конструктивно используется постсоветской психологией как для решения теоретико-познавательных проблем современного человекознания (от социологии и акмеологии до персонологии и космологии), так и насущных задач социальной практики, в том числе развития способностей (Ушаков, 2003; Шадриков, 1996) и человеческого капитала (Иванов, Семенов, 2010) как персонологического (Абульханова и др., 2009; Петровский А.В., 1987; Семенов 2014б) и субъектно-творческого ресурса для культурно-деятельностного развития современной цифровой цивилизации.

\section{Литература}

Абульханова, К. А. (1980). Деятельность и психология личности. М.: Наука.

Абульханова, К. А., Петровский, В. А., Семенов, И. Н. (2009). Психология индивидуальности: новые модели и подходы. М.: МПСИ.

Александров, Ю. И., Брушлинский, А. В., Судаков, К. В. (1999). Системные аспекты психической деятельности. М.: Эдиториал УРСС.

Алексеев, Н. Г. (1962). Проблема творческой активности в изучении структуры деятельности по усвоению знания. В кн. О психологических особенностях творческой активности учащихся (с. 58-63). М.: МГПИ.

Алексеев, Н. Г., Зарецкий, В. К., Семенов, И. Н. (1991). Методология рефлексии концептуальньхх схем деятельности поиска и принятия решений. Новосибирск: НГУ.

Асмолов, А. Г. (1985). Принципы организации памяти: системно-деятельностный подход. М.: Изд-во Московского университета.

Басов, М. Я. (1975). Избранные психологические произведения. М.: Педагогика.

Басов, М. Я. (2007, а). Волево-регуляция внешней деятельности. В кн. М. Я. Басов, Избраннье труды по педагогической психологии (кн. 2, с. 62-73). СПб.: Алетейя.

Басов М. Я. $(2007$, б). Наблюдение человеческих видов деятельности ребенка-дошкольника. В кн. М. Я. Басов, Избранные труды по педагогической психологии (кн. 2, с. 349-414). СПб.: Алетейя.

Басов, М. Я. (2007, в). Развитие человека как активного деятеля в окружающей его среде. Психология развития [1930]. В кн. М. Я. Басов, Избранные труды по педагогической психологии (кн. 1, с. 51-759). СПб.: Алетейя. 
Блонский, П. П. (1979). Марксизм как метод решения педагогических проблем [1924]. В кн. П. П. Блонский, Избранные педагогческие и психологческие сочинения (т. 1, с. 181-186). М.: Педагогика.

Богданов, А. А. (1990, а). Социализм науки: Наука и рабочий класс [1918]. В кн. А. А. Богданов, Вопросы сочиализма: работы разных лет (1904-1924) (с. 177-185). М.: Политиздат.

Богданов, А. А. $(1990$, б). Методы труда и методы познания [1918]. В кн. А. А. Богданов, Вопросы социализма: работы разных лет (1904-1924) (с. 185-193). М.: Политиздат.

Богданов, А. А. (1990, в). Тайна науки [1913]. В кн. А. А. Богданов, Вопросы социализма: работы разных лет (1904-1924) (с. 193-201). М.: Политиздат.

Богданчиков, С. А. (2015). Советская исследовательская и практическая психология 1920-1930-х годов. В кн. А. Л. Журавлев, А. В. Юревич (ред.), Взаимоотношения исследовательской и практической психологии (с. 337-384). М.: Изд-во ИП РАН.

Бодалев, А. А., Климов, Е. А., Семенов, И. Н. (1996). Психология профессиональной деятельности кадров государственной службы. М.: РАГС.

Выготский, Л. С. (1930). О связи между трудовой деятельностью и интеллектуальным развитием ребенка. Педология, 5-6, 588-596.

Гальперин, П. Я. (1998). Проблема деятельности в советской психологии. В кн. П. Я. Гальперин, Психология как объективная наука (с. 249-271). М./Воронеж: НПО «МОДЭК».

Гастев, А. К. (1924). Трудовые установки. М.: Центральный институт труда.

Геллерштейн, С. Г. (1933). О психологии труда в работах К. Маркса. Советская психотехника, $6(1), 1-10$.

Давыдов, В. В., Зинченко, В. П. (1998). Предметная деятельность и онтогенез познания. Вопросы психологии, 5, 11-23.

Днепров, Э. Д. (2007). Педагогика развития и деятельности. В кн. Э. Д. Днепров, Уиинский и современность (с. 212-216). М.: Издательский дом Высшей школы экономики.

Дюков, В. М., Семенов, И. Н., Шайхутдинова, Р. В. (2010). Рефлексивно-деятельностная педагогика: учитель для новой школь. Красноярск: Красноярский писатель.

Журавлев, А. Л. (ред.). (1992). Совместная деятельность: методы исследования и управления. М.: ИП РАН.

Зинченко, Ю. П. (2011). Теоретико-методологические основания психологических исследований: детерминация и социальное значение. М.: Изд-во Московского университета.

Иванов, С. В., Семенов, И. Н. (2010). Рефлексия проблем развития молодежи России как ее социального и человеческого капитала. В кн. Ю. С. Пивоваров (ред.), Россия: тенденции и перспективы развития: ежегодник ИНИОН (вып. 5, ч. 1, с. 146-149). М.: ИНИОН РАН.

Калошина, И. П. (2013). Психология творческой деятельности: учебное пособие. М.: Юнити.

Кан-Калик, В. А. (1977). Педагогическая деятельность как творческий прочесс. М.: Педагогика.

Карпенко, Л. А., Петровский, А. В. (ред.). (2005-2007). Психологический лексикон: Энциклопедический словарь (в 7 т.). М.: ПЭР СЭ.

Карпов, А. В. (2015). Психология деятельности: T. 1. Метасистемный подход. М.: РАО.

Леонтьев, А. А. (2001). Деятельный ум (Деятельность. Знак. Личность). М.: Смысл.

Леонтьев, А. Н. (1975). Деятельность. Сознание. Личность. М.: Политиздат.

Леонтьев, А. Н. (1986). Проблема деятельности в истории советской психологии [1976]. Вопросы психологии, 4, 109-120.

Леонтьев, Д. А. (1998). Психология смысла: природа, строение и динамика смысловой реальности. М.: Смысл. 
Ломов, Б. Ф., Сурков, Е. Н. (1980). Антиципащия в структуре деятельности. М.: Наука.

Любимов, С. Е., Семенов, И. Н. (2015). Научная деятельность Б.М. Теплова и его концепция творчества полководца в процессе практического мышления. Психология. Историко-критические обзоры и современные исследования, 3, 9-51.

Маланов, С. В. (2010). Системно-деятельностный культурно-исторический подход к анализу и объяснению психиеских явлений: объяснительные приниипы и теоретические положения. М.: МПСИ.

Менчинская, Н. А., Ферапонова, Э. А. (ред.). (1977). Проблема деятельности в советской психологии (в 2 ч.). М.: АПН СССР.

Мерлин, В. С. (1982). Индивидуальная система деятельности как опосредующее звено в связях между разноуровневыми свойствами индивидуальности. В кн. Проблемы психологии личности: Советско-финский симпозиум (с. 185-192). М.: Наука.

Некрасов, П. А. (1902). Философия и логика науки о массовых проявлениях человеческой деятельности. М.: Математическое общество, состоящее при Императорском Московском университете.

Петровский, А. В. (1982). Личность, деятельность, коллектив. М.: Политиздат.

Петровский, А. В. (ред.). (1987). Психология развивающейся личности. М.: Педагогика.

Петровский, А. В., Ярошевский, М. Г., Петровский, В. А. (2001). Теоретическая психология. М.: Академия.

Петровский, В. А. (2011). Деятельностное опосредствование межличностных отношений: феномены, сущность. Социальная психология и общество, 1, 5-16.

Пономарев, Я. А. (1981). Психологические механизмы регуляции деятельности. Вопросы психологии, 5, 174-178.

Решетова, 3. А. (ред.). (2002). Формирование системного мьшления в обучении. М.: ЮНИТИ-ДАНА. Рубинштейн, С. Л. (1922). Принцип творческой самодеятельности (К философским основам современной педагогики). В кн. Уиеные записки высшей школы г. Одессы (т. 2, с. 148-154). Одесса.

Рубинштейн, С. Л. (1934). Проблемы психологии в трудах Карла Маркса. Советская психотехника, 7(1), 3-20.

Рубинштейн, С. Л. (1945). Проблема деятельности и сознания в системе советской психологии. Ученые записки Московского университета, 90 (Психология), 6-21.

Сайко, Э. В. (2008). Деятельность как основание акмеологического развития субъекта и надситуативная активность субъекта как действенный фактор ее развития. Мир психологии, 2, 193-205.

Семенов, И. Н. (1970, а). Бехтерев Владимир Михайлович. В кн. П. П. Прохоров (ред.), Большая советская энциклопедия (3-е изд., т. 3, с. 288). М.: Советская энциклопедия.

Семенов, И. Н. (1970, б). Блонский Павел Петрович. В кн. П. П. Прохоров (ред.), Большая советская энциклопедия (3-е изд., т. 3, с. 432). М.: Советская энциклопедия.

Семенов, И. Н. (1971). Выготский Лев Семенович. В кн. П. П. Прохоров (ред.), Большая советская энииклопедия (3-е изд., т. 5, с. 521). М.: Советская энциклопедия.

Семенов, И. Н. (1972, а). Душа. В кн. П. П. Прохоров (ред.), Большая советская энциклопедия (3-е изд., т. 8, с. 554). М.: Советская энциклопедия.

Семенов, И. Н. (1972, б). Индивидуальность. В кн. П. П. Прохоров (ред.), Большая советская энииклопедия (3-е изд., т. 10, с. 188). М.: Советская энциклопедия.

Семенов, И. Н. (1982). Методологические проблемы системного исследования организации мыслительной деятельности. В кн. Д. М. Гвишиани (ред.), Системные исследования. Методологические проблемы. Ежегодник-1982 (с. 301-319). М.: Наука.

Семенов, И. Н. (2013). Эвристичность идей А.А. Богданова как методологических средств постнеклассической психологии рефлексии. В кн. В. Е. Лепский (ред.), Рефлексивные процессы и управление (с. 36-39). М.: Когито-центр. 
Семенов, И. Н. (2014, а). Системодеятельностная методология и рефлексивная психология мьиления. Монография. М.: Институт развития им. Г.П. Щедровицкого.

Семенов, И. Н. (2014, б). Персонология жизнетворчества А.В. Петровского и развитие истории и теории общей и социальной психологии и педагогики. Психология. Историко-критические обзоры и современные исследования, 6, 10-48.

Семенов, И. Н. (2017). Философско-антропологическая проблематика рефлексивной психологии смысла в российском человекознании. Мир психологии, 2, 280-287.

Семенов, И. Н. (2018, а). А.Н. Леонтьев: известный и неизвестный: рефлексивно-культурологическая персонология жизнетворчества. Мир психологии, 2, 282-302.

Семенов, И. Н. (2018, б). Социокультурная рефлексия столетнего развития российской психологической науки: К 100-летию советской психологии (1918-2018). Вестник Московского университета. Серия 14. Психология, 4, 4-31.

Семенов, И. Н. (2019). Первопроходческая роль Е.А. Будиловой в реализации исследовательских программ С.Л. Рубинштейна и методологические проблемы периодизации российской (дореволюционной/советской/постсоветской) психологии. В кн. А. Л. Журавлев, А. Л. Харитонова, Е. В. Холондович (ред.), Историческая преемственность в отечественной психологии (с. 47-67). М.: ИП РАН.

Смирнов, А. А. (1945). Влияние направленности и характера деятельности на запоминание. В кн. Труды института психологии Грузинской ССР (с. 395-426). Тбилиси: Мерецниба.

Теплов, Б. М. (1944). Психологическая характеристика деятельности. Советская педагогика, $11-12,44-53$.

Теплов, Б. М. (1990). Ум полководиа [1945]. М.: Педагогика.

Тихомиров, О. К. (1969). Структура мыслительной деятельности человека. М.: Изд-во Московского университета.

Ушаков, Д. В. (2003). Интеллект: структурно-динамическая теория. М.: Изд-во ИП РАН.

Шадриков, В. Д. (1982). Проблемы системогенеза профессиональной деятельности. М.: Наука.

Шадриков, В. Д. (1996). Психологическая деятельность и способности человека. М.: Логос.

Щедровицкий, Г. П. (1995). Исходные представления и категориальные средства теории деятельности [1975]. В кн. Г. П. Шедровицкий, Избранные труды (с. 233-280). М.: Школа культурной политики.

Юдин, Э. Г. (1978). Системный подход и принцип деятельности: методологические проблемь современной науки. М.: Наука.

Юревич, А. В. (2013). Социальная психология научной деятельности. М.: ИП РАН.

Ярошевский, М. Г. (1984). Предметная деятельность как основа системы психологии. Bопросы психологии, 1, 159-163.

Ссылки на зарубежные источники см. в разделе References после англоязычного блока.

Семенов Игорь Никитович - главный редактор журнала «Психология. Историко-критические обзоры и современные исследования», доктор психологических наук, профессор. Сфера научных интересов: методология и история человекознания, психология мышления и рефлексии, персонология творчества, акмеология управления, гуманизация инновационного образования, педагогика формирования человеческого капитала.

Контакты: I_samenov@mail.ru, Goga.semenov.45@bk.ru 


\title{
The Establishment of Activity Paradigm as a Theoretical and Methodological Dominant of Development of Russian Psychology
}

\author{
I.N. Semenov
}

\begin{abstract}
On the background of a brief analysis of the history of Russian human studies in the 19th 21st centuries, the article depicts the system-forming role of the activity approach as a theoretical and methodological dominant of development of psychological science. First time the full timeline of the activity paradigm is portrayed and the significance of its various concepts for contemporary psychology is shown. Their systemic-activity interaction allowed for us to build a theoretical model, which describes the reflective-personal regulation of cognitive activity (in discursive creative problem-solving) and a reflective mechanism of personal self-development in the process of productive individual self-activity in co-creative cooperation. Ontologically, activity is an object transformation by a subject, mediated both by tools and symbolic means of labor and communication (which are cultural and historical in their origin), and by subjective procedural dynamics of reflective-personal regulation of this transformation. Reflection provides a meaningful reassessment and productive restructuring of the subject's conscious content for his / her adequate orientation in the biotic and social environment as a precondition of adaptive behavior and constructive goal-setting and self-development of individuality in interaction and interrelationship in the process of dialog with other people - contemporaries, predecessors and descendants, which are the links of the relay translation of knowledge and cultures. The system-forming factor of integration of these psychic processes, which provide in complex the realization by a person of social (in its cultural and historical nature) activity, and individual and dialogical behavior in communications, is the reflection as a rethinking and rebuilding by a subject of his / her feelings and content of individual consciousness. In conclusion, the prospective importance of the activity paradigm for the progress of human studies in the 21st century is shown in the interaction of various developmental psychological approaches: anthropological, metacognitive, psychosemantic, reflective, semantic, personological, acmeological, existential, cultural. Their experimental verification allowed developing psychotechnics, effective for modernization of education and management in today's digital age.
\end{abstract}

Keywords: psychology, human studies, philosophy, activity approach, substantive activity, systemic activity, act, behavior, consciousness, reflection, creativity.

\section{References}

Abul'khanova, K. A. (1980). Deyatel'nost' i psikhologiya lichnosti [Activity and psychology of personality]. Moscow: Nauka. (in Russian)

Abul'khanova, K. A., Petrovsky, V. A., \& Semenov, I. N. (2009). Psikhologiya individual'nosti: novye modeli i podkhody [Psychology of individuality: new models and approaches]. Moscow: MPSI.

Aleksandrov, Yu. I., Brushlinskii, A. V., \& Sudakov, K. V. (1999). Sistemnye aspekty psikhicheskoi deyatel'nosti [Systemic aspects of psychic activity]. Moscow: Editorial URSS. (in Russian) 
Alekseev, N. G. (1962). Problema tvorcheskoi aktivnosti v izuchenii struktury deyatel'nosti po usvoeniyu znaniya [The issue of creative activity in the study of the structure of activity in knowledge aquisition]. In O psikhologicheskikh osobennostyakh toorcheskoi aktivnosti uchashchikhsya [On the psychological specifics of creative activity of students] (pp. 58-63). Moscow: MGPI. (in Russian)

Alekseev, N. G., Zaretskii, V. K., \& Semenov, I. N. (1991). Metodologiya refleksii kontseptual'nykh skhem deyatel'nosti poiska i prinyatiya reshenii [Methodology of reflection on conceptual schemes for search activity and decision-making]. Novosibirsk: NGU. (in Russian)

Asmolov, A. G. (1985). Printsipy organizatsii pamyati: sistemno-deyatel'nostnyi podkhod [Principles of memory organization: systemic-activity approach]. Moscow: Moscow State University Press. (in Russian)

Basov, M. Ya. (1975). Izbrannye psikhologicheskie proizvedeniya [Selected psychological works]. Moscow: Pedagogika. (in Russian)

Basov, M. Ya. (2007, a). Volevo-regulyatsiya vneshnei deyatel'nosti [Volitional regulation of external activity]. In M. Ya. Basov, Izbrannye trudy po pedagogicheskoi psikhologii [Selected works in organizational psychology] (Vol. 2, pp. 62-73). Saint Petersburg: Aleteiya. (in Russian)

Basov M. Ya. (2007, b). Nablyudenie chelovecheskikh vidov deyatel'nosti rebenka-doshkol'nika [Observation of human types of activity of a preschool child]. In M. Ya. Basov, Izbrannye trudy po pedagogicheskoi psikhologii [Selected works in pedagogical psychology] (Vol. 2, pp. 349-414). Saint Petersburg: Aleteiya. (in Russian)

Basov, M. Ya. (2007, c). Razvitie cheloveka kak aktivnogo deyatelya v okruzhayushchei ego srede. Psikhologiya razvitiya [Development of man as an actor in his environment. Developmental psychology] [1930]. In M. Ya. Basov, Izbrannye trudy po pedagogicheskoi psikhologii [Selected works in pedagogical psychology] (Vol. 1, pp. 51-759). Saint Petersburg: Aleteiya. (in Russian)

Blonskii, P. P. (1979). Marksizm kak metod resheniya pedagogicheskikh problem [Marxism as a method of solving pedagogical problems] [1924]. In P. P. Blonskii, Izbrannye pedagogicheskie i psikhologicheskie sochineniya [Selected pedagogical and psychological works] (Vol. 1, pp. 181186). Moscow: Pedagogika. (in Russian)

Bodalev, A. A., Klimov, E. A., \& Semenov, I. N. (1996). Psikhologiya professional'noi deyatel'nosti kadrov gosudarstvennoi sluzhby [Psychology of professional activity of the personnel of civil service]. Moscow: RAGS. (in Russian)

Bogdanchikov, S. A. (2015). Sovetskaya issledovatel'skaya i prakticheskaya psikhologiya 1920-1930kh godov [Soviet research and applied psychology]. In A. L. Zhuravlev \& A. V. Yurevich (Eds.), Vzaimootnosheniya issledovatel'skoi i prakticheskoi psikhologii [Interrelationships of research and applied psychology] (pp. 337-384). Moscow: Institute of Psychology of the RAS. (in Russian)

Bogdanov, A. A. (1990, a). Sotsializm nauki: Nauka i rabochii klass [Socialism of science: Science and the working class] [1918]. In A. A. Bogdanov, Voprosy sotsializma: raboty raznykh let [Issues of socialism: Works of various years] (1904-1924) (pp. 177-185). Moscow: Politizdat. (in Russian)

Bogdanov, A. A. (1990, b). Metody truda i metody poznaniya [1918] [Methods of labor and methods of knowledge]. In A. A. Bogdanov, Voprosy sotsializma: raboty raznykh let [Issues of socialism: Works of various years] (1904-1924) (pp. 185-193). Moscow: Politizdat. (in Russian)

Bogdanov, A. A. (1990, c). Taina nauki [The secret of science] [1913]. In A. A. Bogdanov, Voprosy sotsializma: raboty raznykh let [Issues of socialism: Works of various years] (1904-1924) (pp. 193201). Moscow: Politizdat. (in Russian)

Davydov, V. V., \& Zinchenko, V. P. (1998). Object activity and ontogenesis of cognition. Voprosy Psikhologii, 5, 11-23. (in Russian) 
Dneprov, E. D. (2007). Pedagogika razvitiya i deyatel'nosti [Pegagogy of development and activity]. In E. D. Dneprov, Ushinskii i sovremennost' [Ushinsky and modernity] (pp. 212-216). Moscow: HSE Publishing House. (in Russian)

Dyukov, V. M., Semenov, I. N., \& Shaikhutdinova, R. V. (2010). Refleksiono-deyatel'nostnaya pedagogika: uchitel' dlya novoi shkoly [Reflective-activity pedagogy: a teacher for a new school]. Krasnoyarsk: Krasnoyarskii pisatel'. (in Russian)

Gal'perin, P. Ya. (1998). Problema deyatel'nosti v sovetskoi psikhologii [The issue of activity in the Soviet psychology]. In P. Ya. Gal'perin, Psikhologiya kak ob"ektionaya nauka [Psychology as an objective science] (pp. 249-271). Moscow/Voronezh: NPO "MODEK". (in Russian)

Gastev, A. K. (1924). Trudozye ustanozki [Labor attitudes]. Moscow: Tsentral'nyi institut truda. (in Russian)

Gellerstein, S. G. (1933). O psikhologii truda v rabotakh K. Marksa [On the psychology of labor in the works of K. Marx]. Sovetskaya Psikhotekhnika, 6(1), 1-10. (in Russian)

Ivanov, S. V., \& Semenov, I. N. (2010). Refleksiya problem razvitiya molodezhi Rossii kak ee sotsial'nogo i chelovecheskogo kapitala [Reflection on the developmental problems of the Russian youth as its social and human capital]. In Yu. S. Pivovarov (Ed.), Rossiya: tendentsii i perspektivy razvitiya: ezhegodnik INION [Russia: tendencies and perspectives of development: INION yearbook] (Iss. 5, Pt. 1, pp. 146-149). Moscow: INION RAN. (in Russian)

Kaloshina, I. P. (2013). Psikhologiya tvorcheskoi deyatel'nosti [The psychology of creative activity]. Moscow: Yuniti. (in Russian)

Kan-Kalik, V. A. (1977). Pedagogicheskaya deyatel'nost' kak toorcheskii protsess [Pedagogical activity as a creative process]. Moscow: Pedagogika. (in Russian)

Karpenko, L. A., \& Petrovskii, A. V. (Eds.). (2005-2007). Psikhologicheskii leksikon: Entsiklopedicheski slovar' [Psychological lexicon: Encyclopedic dictionary] (in 7 vols.). Moscow: PER SE. (in Russian)

Karpov, A. V. (2015). Psikhologiya deyatel'nosti: Vol. 1. Metasistemnyi podkhod [Psychology of activity: Vol.1. Metasystemic approach]. Moscow: RAO. (in Russian)

Leontiev, A. A. (2001). Deyatel'nyi um (Deyatel'nost'. Znak. Lichnost') [Active mind (Activity. Symbol. Personality)]. Moscow: Smysl. (in Russian)

Leontiev, A. N. (1975). Deyatel'nost'. Soznanie. Lichnost' [Activity. Consciousness. Personality]. Moscow: Politizdat. (in Russian)

Leontiev, A. N. (1986). Problema deyatel'nosti v istorii sovetskoi psikhologii [The issue of activity in the history of Soviet psychology] [1976]. Voprosy Psikhologii, 4, 109-120. (in Russian)

Leontiev, D. A. (1998). Psikhologiya smysla: priroda, stroenie i dinamika smyslovoi real'nosti [The psychology of meaning: the nature, structure and dynamics of the meaningful reality]. Moscow: Smysl. (in Russian)

Lomov, B. F., \& Surkov, E. N. (1980). Antitsipatsiya v strukture deyatel'nosti [Anticipation in the structure of activity]. Moscow: Nauka. (in Russian)

Lyubimov, S. E., \& Semenov, I. N. (2015). The scientific activities of B.M. Teplov and his conception of a commander's creativity in the process of practical thinking. Psikhologiya. Istoriko-kriticheskie Obzory i Sovremennye Issledovaniya [Psychology. Historical-critical Revieres and Current Researches], 3, 9-51. (in Russian)

Malanov, S. V. (2010). Sistemno-deyatel'nostnyi kul'turno-istoricheskii podkhod k analizu i ob»yasneniyu psikhicheskikh yavlenii: ob "yasnitel'nye printsipy i teoreticheskie polozheniya [Systemic-activity cultural-historical approach to the analysis and interpretation of psychic phenomena: interpretational principles and theoretical theses]. Moscow: MPSI. (in Russian) 
Matthaus, W. (1988). Sorøetische Denkpsychologie. Gottingen/Toronto/Zurich: Verlag für Psychologie. Menchinskaya, N. A., \& Feraponova, E. A. (Eds.). (1977). Problema deyatel'nosti v sovetskoi psikhologii The issue of activity in the Soviet psychology] (in 2 pts.). Moscow: APN SSSR. (in Russian)

Merlin, V. S. (1982). Individual'naya sistema deyatel'nosti kak oposreduyushchee zveno v svyazyakh mezhdu raznourovnevymi svoistvami individual'nosti [Individual system of activity as a mediational link between the split-level properties of individuality]. In Problemy psikhologii lichnosti: Sovetsko-finskii simpozium [Issues of personality psychology: Soviet-Finnish Symposium] (pp. 185-192). Moscow: Nauka. (in Russian)

Nekrasov, P. A. (1902). Filosofiya i logika nauki o massovykh proyavleniyakh chelovecheskoi deyatel'nosti [The philosophy and logics of science of the mass manifestation of human activity]. M.: Matematicheskoe obshchestvo, sostoyashchee pri Imperatorskom Moskovskom universitete. (in Russian)

Petrovskii, A. V. (1982). Lichnost', deyatel'nost', kollektiv [Personality, activity, collective]. Moscow: Politizdat. (in Russian)

Petrovskii, A. V. (Ed.). (1987). Psikhologiya razvivayushcheisya lichnosti [The psychology of the developing personality]. Moscow: Pedagogika. (in Russian)

Petrovskii, A. V., Yaroshevskii, M. G., \& Petrovsky, V. A. (2001). Teoreticheskaya psikhologiya [Theoretical psychology]. Moscow: Akademiya. (in Russian)

Petrovsky, V. A. (2011). Deyatel'nostnoe oposredstvovanie mezhlichnostnykh otnoshenii: fenomeny, sushchnost' [Activity mediation of the interpersonal relations: phenomena, essence]. Sotsial'naya Psikhologiya i Obshchestvo, 1, 5-16. (in Russian)

Ponomarev, Ya. A. (1981). Psikhologicheskie mekhanizmy regulyatsii deyatel'nosti [Psychological mechanisms of activity regulation]. Voprosy Psikhologii, 5, 174-178. (in Russian)

Reshetova, Z. A. (Ed.). (2002). Formirovanie sistemnogo myshleniya v obuchenii [The formation of systemic thinking in education]. Moscow: YuNITI-DANA. (in Russian)

Rubinstein, S. L. (1922). Printsip tvorcheskoi samodeyatel'nosti (K filosofskim osnovam sovremennoi pedagogiki) [The principle of creative self-activity (To the philosophical basis of modern pedagogy]. In Uchenye zapiski vysshei shkoly g. Odessy [The scientific notes of the higher school of the city of Odessa] (Vol. 2, pp. 148-154). Odessa, RU. (in Russian)

Rubinstein, S. L. (1934). Problemy psikhologii v trudakh Karla Marksa [The issues of psychology in the works by Karl Marx]. Sovetskaya Psikhotekhnika, 7(1), 3-20. (in Russian)

Rubinstein, S. L. (1945). Problema deyatel'nosti i soznaniya v sisteme sovetskoi psikhologii [The issue of activity and consciousness in the system of the Soviet psychology]. Uchenye Zapiski Moskovskogo Universiteta, 90 (Psychology), 6-21. (in Russian)

Saiko, E. V. (2008). Deyatel'nost' kak osnovanie akmeologicheskogo razvitiya sub»ekta i nadsituativnaya aktivnost' sub"ekta kak deistvennyi faktor ee razvitiya [Activity as a basis of acmeological development of a subject and over-the-situation activity of a subject as an effective factor of its development]. Mir Psikhologii, 2, 193-205. (in Russian)

Semenov, I. N. (1970, a). Bekhterev Vladimir Mikhailovich. In P. P. Prokhorov (Ed.), Bol'shaya sovetskaya entsiklopediya [The big Soviet encyclopedia] (3rd ed., Vol. 3, p. 288). Moscow: Sovetskaya entsiklopediya. (in Russian)

Semenov, I. N. (1970, b). Blonskii Pavel Petrovich. In P. P. Prokhorov (Ed.), Bol'shaya sovetskaya entsiklopediya [The big Soviet encyclopedia] (3rd ed., Vol. 3, p. 432). Moscow: Sovetskaya entsiklopediya. (in Russian)

Semenov, I. N. (1971). Vygotsky Lev Semenovich. In P. P. Prokhorov (Ed.), Bol'shaya sovetskaya entsiklopediya [The big Soviet encyclopedia] (3rd ed., Vol. 5, p. 521). Moscow: Sovetskaya entsiklopediya. (in Russian) 
Semenov, I. N. (1972, a). Dusha [Soul]. In P. P. Prokhorov (Ed.), Bol'shaya sovetskaya entsiklopediya [The big Soviet encyclopedia] (3rd ed., Vol. 8, p. 554). Moscow: Sovetskaya entsiklopediya. (in Russian)

Semenov, I. N. (1972, b). Individual'nost' [Individuality]. In P. P. Prokhorov (Ed.), Bol'shaya sovetskaya entsiklopediya [The big Soviet encyclopedia] (3rd ed., Vol. 10, p. 188). Moscow: Sovetskaya entsiklopediya. (in Russian)

Semenov, I. N. (1982). Metodologicheskie problemy sistemnogo issledovaniya organizatsii myslitel'noi deyatel'nosti [Methodological problems of the systemic research on organization of cognitive activity]. In D. M. Gvishiani (Ed.), Sistemnye issledovaniya. Metodologicheskie problemy. Ezhegodnik-1982 [Systemic studies. Methodological problems. Yearbook-1982] (pp. 301-319). Moscow: Nauka. (in Russian)

Semenov, I. N. (2013). Evristichnost' idei A.A. Bogdanova kak metodologicheskikh sredstv postneklassicheskoi psikhologii refleksii [Heuristicity of the ideas]. In V. E. Lepskii (Ed.), Refleksiznye protsessy i upravlenie [Reflective processes and management] (pp. 36-39). Moscow: Kogito-tsentr. (in Russian)

Semenov, I. N. (2014, a). Sistemodeyatel'nostnaya metodologiya i refleksionaya psikhologiya myshleniya [Systemic-activity methodology and reflective psychology of thinking]. Moscow: Institut razvitiya im. G.P. Shchedrovitskogo. (in Russian)

Semenov, I. N. (2014, b). Personology of creating life in works of A.V. Petrovskii and the development of the history and theory of general and social psychology and pedagogy (the 90th anniversary of his birth). Psikhologiya. Istoriko-kriticheskie Obzory i Sovremennye Issledovaniya [Psychology. Historical-critical Reviewes and Current Researches], 6, 10-48. (in Russian)

Semenov, I. N. (2017). Filosofsko-antropologicheskaya problematika refleksivnoi psikhologii smysla v rossiiskom chelovekoznanii [Philosophical-anthropological problematics of reflective psychology of meaning in the Russian human studies]. Mir Psikhologii, 2, 280-287. (in Russian)

Semenov, I. N. (2018, a). A.N. Leontiev: izvestnyi i neizvestnyi: refleksivno-kul'turologicheskaya personologiya zhiznetvorchestva [Leontiev: the known and the unknown: reflective-cultural personology of creative life ]. Mir Psikhologii, 2, 282-302. (in Russian)

Semenov, I. N. (2018, b). Russian psychology hundred-year development, sociocultural reflection: to the centenary of Soviet psychology (1918-2018). Moscow University Psychology Bulletin, 4, 4-31. (in Russian)

Semenov, I. N. (2019). Pervoprokhodcheskaya rol' E.A. Budilovoi v realizatsii issledovatel'skikh programm S.L. Rubinshteina i metodologicheskie problemy periodizatsii rossiiskoi (dorevolyutsionnoi/sovetskoi/postsovetskoi) psikhologii [The pioneering role of E.A. Budilova in realization of research programs by S.L. Rubinshtein, and methodological problems of periodization of the Russian (before Revolution/Soviet/Post-Soviet) psychology]. In A. L. Zhuravlev, A. L. Kharitonova, \& E. V. Kholondovich (Eds.), Istoricheskaya preemstvennost'v otechestvennoi psikhologii [Historical succession in the Russian psychology] (pp. 47-67). Moscow: Institute of Psychology of the RAS. (in Russian)

Semionov, I. N. (1978). An empirical psychological study of thought processes in creative problemsolving from the perspective of the theory of activity. Soviet Psychology, 16(4), 3-46.

Shadrikov, V. D. (1982). Problemy sistemogeneza professional'noi deyatel'nosti [The issues of systemogenesis of professional activity]. Moscow: Nauka. (in Russian)

Shadrikov, V. D. (1996). Psikhologicheskaya deyatel'nost' i sposobnosti cheloveka [Psychological activity and the human abilities]. Moscow: Logos. (in Russian) 
Shchedrovitskii, G. P. (1995). Iskhodnye predstavleniya i kategorial'nye sredstva teorii deyatel'nosti [The initial beliefs and categorical means of the theory of activity] [1975]. In G. P. Shchedrovitskii, Izbrannye trudy [Selected works] (pp. 233-280). Moscow: Shkola kul'turnoi politiki. (in Russian) Smirnov, A. A. (1945). Vliyanie napravlennosti i kharaktera deyatel'nosti na zapominanie [The influence of the activity's orientation and character on memory]. In Trudy Instituta psikhologii Gruzinskoi SSR [The works of the Institute of psychology of the Georgian SSR] (pp. 395-426). Tbilisi: Meresniba. (in Russian)

Teplov, B. M. (1944). Psikhologicheskaya kharakteristika deyatel'nosti. [The psychological characteristics of activity]. Sovetskaya Pedagogika, 11-12, 44-53. (in Russian)

Teplov, B. M. (1990). Um polkovodtsa [The mind of the commander] [1945]. Moscow: Pedagogika. (in Russian)

Tikhomirov, O. K. (1969). Struktura myslitel'noi deyatel'nosti cheloveka [The structure of human cognitive activity]. Moscow: Moscow University Press. (in Russian)

Ushakov, D. V. (2003). Intellekt: strukturno-dinamicheskaya teoriya [Intelligence: structural-dynamic theory]. Moscow: Institute of Psychology of the RAS. (in Russian)

Vygotsky, L. S. (1930). O svyazi mezhdu trudovoi deyatel'nost'yu i intellektual'nym razvitiem rebenka [On the link between labor activity and intellectual development of a child]. Pedologiya, 5-6, 588596. (in Russian)

Wertsch, J. W., \& Vygotskii, L. S. (1981). The concept of activity in Soviet psychology. Armonk, NY: M.E. Sharp, Inc.

Yaroshevskii, M. G. (1984). Predmetnaya deyatel'nost' kak osnova sistemy psikhologii [The substantive activity as a basis of psychology's system]. Voprosy Psikhologii, 1, 159-163. (in Russian)

Yudin, E. G. (1978). Sistemnyi podkhod i printsip deyatel'nosti: metodologicheskie problemy sovremennoi nauki [Systemic approach and the principle of activity: methodological problems of the contemporary science]. Moscow: Nauka. (in Russian)

Yurevich, A. V. (2013). Sotsial'naya psikhologiya nauchnoi deyatel'nosti [Social psychology of scientific activity]. Moscow: Institute of Psychology of the RAS. (in Russian)

Zhuravlev, A. L. (Ed.). (1992). Sovmestnaya deyatel'nost': metody issledovaniya i upravleniya [Joint activity: methods of study and management]. Moscow: Institute of Psychology of the RAS. (in Russian)

Zinchenko, Yu. P. (2011). Teoretiko-metodologicheskie osnovaniya psikhologicheskikh issledovanii: determinatsiya i sotsial'noe znachenie [Theoretical and methodological basis of psychological studies: determination and social importance]. Moscow: Moscow University Press. (in Russian)

Igor N. Semenov - Editor-in-chief of Journal "Psychology. Historical-critical Reviews and Current Researches", DSc in Psychology, professor.

Research Area: methodology and history of the science of man, psychology of thinking and reflection, personology of creativity, acmeology of management, humanization of innovational education, pedagogy of formation of human capital.

E-mail: I_samenov@mail.ru, Goga.semenov.45@bk.ru 